\title{
Dampak Covid-19 Terhadap Pengelolaan Agrowisata Perkebunan Teh Sirah Kencong Kabupaten Blitar sebagai Obyek Wisata Berkelanjutan
}

\author{
Radite Wanudya Apsari ${ }^{1}$, Egi Nursari Billah ${ }^{2}$, Nailul Insani ${ }^{3}$ \\ Universitas Negeri Malang, Jl. Semarang 5 Malang 65145 Jawa Timur Indonesia \\ ${ }^{1}$ radite.wanudya.1807226@students.um.ac.id; ${ }^{2}$ egi.nursari.1807226@students.um.ac.id; ${ }^{3}$ nailul.insani.fis@um.ac.id
}

ARTICLE INFO

Article history:

Received: October 16, 2020

Reviewed: November 10, 2020

Accepted: November 26, 2020

Published: December 21, 2020

Keyword: Dual commercial economy, economic development, interaction, sharia tourism

\section{ABSTRACT}

The development of tourism in Indonesia must be supported by infrastructure development so that it can spur an increase in the number of tourists. The tourism industry plays a very important role in determining environmentally friendly tourism options. The spread of Covid-19 which continues to increase will have an impact on tourism management. This study aims to examine how the impact of Covid-19 on the management of Sirah Kencong Agro tourism as a sustainable tourism object. This research was conducted in the Sirah Kencong Tea Plantation, which is in the administrative area of Blitar Regency, East Java. The method used in this research is the descriptive method with qualitative analysis techniques. The data used in this study are primary data and secondary data. Primary data collection in this study used the method of observation and interviews based on Sapta Pesona Indonesia. Secondary data collection is obtained from literature studies and studying documents from related agencies. Tourism management at Sirah Kencong Agrotourism is carried out by following health protocols such as visitors having to wear masks, wash their hands when entering tourist areas, and maintain distance between visitors. Other natural potentials can be utilized and developed, of course, by looking at aspects related to promoting sustainable tourism.

\section{ABSTRAK}

Perkembangan kepariwisataan di Indonesia harus ditunjang dengan pembangunan infrastruktur, sehingga dapat memacu pertambahan jumlah wisatawan. Industri pariwisata sangat berperan dalam menentukan opsi wisata yang ramah terhadap lingkungan. Penyebaran Covid-19 yang terus mengalami peningkatan akan berdampak pada pengelolaan wisata. Penelitian ini bertujuan untuk mengkaji bagaimana dampak Covid-19 terhadap pengelolaan Agrowisata Sirah Kencong sebagai obyek wisata berkelanjutan. Penelitian ini dilakukan di Kawasan Perkebunan Teh Sirah Kencong yang berada dalam wilayah administrasi Kabupaten Blitar Jawa Timur. Metode yang digunakan dalam penelitian ini adalah metode deskriptif dengan teknik analisis kualitatif. Data yang digunakan dalam penelitian ini adalah data primer dan data sekunder. Pengumpulan data primer dalam penelitian ini menggunakan metode observasi dan wawancara yang berpedoman pada Sapta Pesona Indonesia. Pengumpulan data sekunder didapat dari studi literatur dan mempelajari dokumen dari instansi terkait. Manajemen pariwisata di Agrowisata Sirah Kencong dilakukan dengan mengikuti protokol kesehatan seperti pengunjung harus memakai masker, mencuci tangan saat memasuki area wisata, dan 
menjaga jarak antar pengunjung. Potensi alam lainya dapat dimanfaatkan dan dikembangkan tentunya dengan melihat aspek yang terkait dengan mengedepankan pariwisata secara berkelanjutan.

Copyright () 2019 Politeknik Negeri Samarinda. All rights reserved.

\section{Pendahuluan}

Kepariwisataan adalah sektor di Indonesia yang mengalami peningkatan di setiap tahunnnya. Hal ini ditunjang dari potensi yang dimiliki yaitu berupa potensi alam dan keanekaragaman budaya. Perkembangan kepariwisataan di Indonesia harus ditunjang dengan pembangunan infrastruktur, sehingga dapat memacu pertambahan jumlah wisatawan. Sektor pariwisata daerah harus dapat meningkatkan pendapatan daerah, meningkatkan perekonomian masyarakat, serta ramah terhadap lingkungan (Rahma \& Primasworo, 2018).

Dalam beberapa tahun terakhir ini terdapat gerakan yang sangat antusias untuk mengembangkan pariwisata ramah lingkungan, sebagai usaha mengimbangi pariwisata massal yang dalam banyak hal tidak mempertahankan kelestarian lingkungan, malahan cenderung merusak lingkungan. Hal ini disebabkan karena kedua jenis pariwisata ini mempunyai pandangan yang sangat berbeda. Ekoturisme mempunyai sikap usaha wisata dengan senantiasa berpegang pada pandangan sedapat mungkin mempertahankan keindahan alam yang mempunyai daya tarik tersendiri dan sangat berharga ditinjau, baik dari sudut sosialbudaya maupun ekonomi. Sebaliknya, wisata massal berpandangan bagaimana mengeruk keuntungan dari wisatawan sebanyak mungkin. Akibatnya, lingkungan menjadi persoalan terakhir dalam hitungan (Yoeti, 2000).

Terbentuknya wisata ramah lingkungan sangat penting bagi wisatawan. Sebanyak 93\% wisatawan di Indonesia menganggap bahwa tren wisata ramah lingkungan cukup penting apalagi berguna untuk menghilangkan penat saat berakhir pekan. Bahkan $76 \%$ wisatawan menjalani kehidupan yang lebih ramah lingkungan. Untuk itu, industri pariwisata sangat berperan dalam menentukan opsi wisata yang ramah lingkungan, karena masih banyak wisatawan yang tidak memahami bagaimana cara memilih opsi tersebut. Industri pariwisata juga dapat memberikan edukasi mengenai opsi-opsi wisata ramah lingkungan yang ditawarkan kepada wisatawan (Dianawanti, 2020). Salah satu contoh wisata ramah lingkungan berada di Kabupaten Blitar. Di sana terdapat kawasan Kampung Wisata Ekologis (KWE) "Puspa Jagad" yang berada di Desa Semen, Kecamatan Gandusari, Kabupaten Blitar yang didirikan pada tahun 2007. Kampung Wisata Ekologis ini memiliki kegiatan utama yang ditawarkan yaitu konservasi Anggrek Alam dengan program pelengkap berupa outbond. (Sawindri, 2016). Penawaran kegiatan konservasi tersebut merupakan opsi yang ditawarkan oleh Kampung Wisata Ekologis. Dengan demikian, peningkatan tren wisata ramah lingkungan juga berdampak pada pembentukan karakter wisatawan yang lebih peduli terhadap lingkungan.

Kabupaten Blitar secara morfologi dibagi menjadi dua bagian yaitu Blitar Utara dan Blitar Selatan yang dibatasi oleh aliran sungai Brantas. Hal ini sekaligus membedakan potensi kedua wilayah tersebut yang mana Blitar Utara merupakan dataran rendah lahan sawah dan beriklim basah dan Blitar Selatan merupakan lahan kering yang cukup kritis dan beriklim kering. Wilayah Blitar selatan terus berusaha mengembangkan segala potensi yang dimiliki. Daya tarik potensi dan kekayaan yang dimiliki Kabupaten Blitar bukan hanya pada sumber daya alam, produksi hasil bumi yang melimpah, hasil - hasil peternakan, perikanan dan deposit hasil tambang yang tersebar di wilayah Blitar Selatan saja, tetapi juga kekayaan budaya serta peninggalan sejarah yang mempunyai nilai adiluhung menjadi kekayaan yang tidak ternilai (Pemerintah Kabupaten Blitar, 2020c).

Kabupaten Blitar bagian utara memiliki kawasan perkebunan teh yang luas yaitu Perkebuan Teh Sirah Kencong yang termasuk bagian dari PT Perkebunan Nusantara XII Bantaran dengan lokasi administratif berada di Desa Ngadirenggo Kecamatan Wlingi. Mata pencaharian 
penduduk di Dukuh Sirah Kencong sebagian besar sebagai karyawan dan buruh perkebunan teh. Buruh perkebunan teh ini tidak hanya dari masyarakat sekitar namun juga ada dari desa lain yakni Desa Balerejo Kecamatan Wlingi.

Penyebaran Corona Virus Disease 2019 (Covid-19) di wilayah Kabupaten Blitar terus mengalami peningkatan. Peningkatan tersebut diperoleh dari data per tanggal 7 Oktober 2020 pukul 14.00 WIB. Data tersebut menunjukkan bahwa terdapat penambahan 12 pasien yang terkonfirmasi positif Covid-19, sehingga kasus positif Covid-19 mencapai 628 orang. Sementara itu, jumlah Pasien Dalam Pengawasan (PDP) juga bertambah 12 orang, sehingga totalnya menjadi 45 orang. Tetapi dibalik itu semua, kasus pasien yang sembuh juga meningkat walaupun peningkatannya tidak terlalu signifikan. Jumlah pasien yang sembuh mencapai 537 orang dari sebelumnya sekitar 528 orang. Berdasarkan data dari Dinas Kesehatan, dari 22 kecamatan yang ada, 14 diantaranya berstatus zona merah (Dinas Kesehatan Kabupaten Blitar, 2020).

Berdasarkan data tersebut, dampak pandemi Covid-19 menurunkan target Pendapatan Asli Daerah (PAD) di sektor wisata Kabupaten Blitar. Target PAD di sektor pariwisata diturunkan sekitar 31 persen menjadi $\mathrm{Rp} 1,4$ miliar dari sebelumnya sebesar Rp 2,1 miliar pada 2020. Penurunan PAD di sektor pariwisata adalah dampak dari kebijakan pemerintah dalam upaya pencegahan Covid-19. Penurunan PAD juga disebabkan karena status zona merah di Kabupaten Blitar yang meningkat, sehingga pemerintah mengeluarkan surat edaran dengan menutup sementara semua tempat hiburan dan tempat wisata. Tujuan dari penutupan ini adalah untuk memutus rantai penyebaran Covid-19 (Hadi, 2020).

\section{Review Tinjauan Pustaka Pandemi Covid-19}

Coronavirus merupakan virus yang menyebabkan penyakit pada manusia dan hewan. Penyakit ini dapat menyebabkan infeksi saluran pernapasan pada manusia. Gejala penyakit ini ditandai mulai dari flu biasa hingga penyakit yang lebih serius seperti Middle East Respiratory Syndrome (MERS) dan Severe Acute Respiratory
Syndrome (SARS). Sejak muncul di Wuhan China pada Desember 2019 lalu, coronavirus merupakan virus jenis baru yang ditemukan oleh manusia. Virus ini kemudian diberi nama Severe Acute Respiratory Syndrome Coronavirus 2 (SARS-COV2) yang menyebabkan penyakit Coronavirus Disease2019 (COVID-19). SAR-COV2 masih termasuk dalam keluarga besar coronavirus yang sama penyebab penyakit SARS yang terjadi pada tahun 2003, hanya jenis virusnya saja yang berbeda. Virus ini mempunyai gejala yang hampir mirip, namun penyakit SARS memiliki angka kematian yang jauh lebih tingggi dibandingkan dengan penyakit Covid-19. Angka kematian pada penyakit SARS mencapai 9,6\% sedangkan pada penyakit Covid-19 tidak sampai mencapai 5\% (kurang dari 5\%). Meskipun penyakit SARS memiliki angka kematian yang tinggi, tetapi jumlah kasus penyakit ini tidak sebanyak pada penyakit Covid-19. Penyakit SARS juga tidak memiliki penyebaran yang luas dan cepat ke beberapa negara dibanding dengan penyakit Covid-19 (Kementrian Kesehatan Repulik Indonesia, 2020).

Di Indonesia, kasus Covid-19 pertama kali dilaporkan pada 2 Maret 2020 dengan dua kasus positif Covid-19. Pertumbuhan kasus yang dikonfirmasi oleh Pemerintah Indonesia terus mengalami peningkatan yang signifikan. Pada 30 Maret 2020 pertumbuhan kasus mencapai 1.285 kasus. Beberapa negara di kawasan Asia Tenggara mengumumkan penularan coronavirus sejak bulan Januari, kecuali Indonesia pada bulan Maret. Namun jumlah kasus di beberapa negara di kawasan Asia Tenggara telah dilampaui oleh Indonesia (Wuragil, 2020). Bahkan tingkat mortalitas akibat Covid-19 mencapai 4,2\% per 31 Agustus 2020. Angka ini jauh lebih tinggi dibandingkan dengan tingkat mortalitas rata-rata di dunia yang hanya sebesar 3,34\% (Farisa, 2020).

Banyak faktor yang dapat mempengaruhi percepatan kemunculan penyakit baru. Faktor-faktor tersebut dapat menyebabkan perkembangan agen infeksi menjadi bentuk ekologis yang baru, mudah menjangkau inang yang baru sehingga dalam beradaptasi dan penyebarannya di antara inang-inang baru tersebut sangat mudah. Faktor-faktor tersebut termasuk urbanisasi dan penghancuran habitat asli. Hal ini memungkinkan bahwa manusia dan hewan 
hidup dalam jarak dekat, kemungkinan adanya perubahan iklim dan ekosistem, populasi inang reservoir atau vektor serangga juga dapat berubah, dan adanya kemungkinan mutasi genetik mikroba. Dengan demikian, dampak dari penyakit baru tersebut sulit untuk diprediksi. Hal tersebut dikarenakan sistem kekebalan setiap orang berbeda-beda, sehingga ada beberapa orang yang memiliki sedikit kekebalan terhadap suatu penyakit atau tidak sama sekali (Kementrian Kesehatan Repulik Indonesia, 2020).

\section{Pengertian Agrowisata}

Agrowisata adalah suatu jenis sektor usaha percampuran antara pertanian (agriculture) dan wisata. Wisata merupakan suatu kegiatan singkat dengan sukarela untuk menikmati objek wisata, sehingga agrowisata merupakan suatu kegiatan singkat dengan sukarela untuk menikmati objek wisata yang berbasis pertanian (Islamiarani, 2008). Agrowisata dapat dikelompokkan ke dalam wisata ekologi (eco-toursm), yaitu kegiatan perjalanan wisata dengan tidak merusak atau mencemari alam dengan tujuan untuk mengagumi dan menikmati keindahan alam, hewan atau tumbuhan liar di lingkungan alaminya serta sebagai sarana pendidikan. Wisata ekologi (eco-toursm) meliputi serangkaian jenis wisata yang berlandaskan pada pengkaitan antara kegiatan wisata dengan konservasi alam (Ernaldi, 2010).

\section{Pengembangan Pariwisata Berkelanjutan}

Pengembangan pariwisata berkelanjutan dapat diartikan sebagai pengembangan wisata yang berwawasan lingkungan dengan tidak merusak kondisi sumberdaya alam sekitar sehingga dapat dimanfaatkan terus-menerus hingga ke generasi yang akan datang. Konsep pariwisata bekelanjutan harus dapat memberikan manfaat ekonomi terhadap masyarakat sekitar (Djafar, 2015).

Pembangunan pariwisata berkelanjutan harus memanfaatkan sumber daya alam secara optimal sesuai daya dukung sehingga tidak menimbulkan kerusakan, menghormati sosial budaya masyarakat, memastikan manfaat ekonomi yang berkelanjutan serta terdistribusi secara adil pada seluruh stakeholders. Pengelola juga tidak boleh hanya memikirkan bagaimana meningkatkan jumlah pengunjung tetapi tidak menghiraukan kesesuaian yang sebenarnya menjadi acuan suatu kawasan wisata sehingga tetap lestari dan berkelanjutan. Kesesuaian wisata untuk kegiatan rekreasi agro harus memperhatikan karakteristik lingkungan tersebut (Insani et al., 2019).

\section{Prinsip Konservasi}

Manajemen ekowisata yang memenuhi kaidah konservasi memerlukan penjelasan rinci tentang sistem produksi ekowisata secara keseluruhan (from cradle to the grave). Suatu obyek tujuan wisata memiliki karakteristik sistem produksi yang berbeda dengan tujuan wisata lainnya. Belum mencakup perbedaan dalam karakteristik sosial dan pengelolaan ekosistem. Pengenalan terhadap sistem produksi berguna untuk mengidentifikasi isu kritis yang berkaitan dengan konservasi. Berangkat dari isu tersebut kemudian dapat dirumuskan rencana strategis (strategic planning) dalam memecahkan permasalahan untuk menuju pemanfaatan sumber daya secara berkelanjutan (Nugroho, 2011).

\section{Kontribusi Ekowisata terhadap Konservasi \\ Keterlibatan penduduk lokal dalam} aktivitas ekowisata merupakan komponen keberlanjutan pengelolaan. Pengelolaan ini dapat ditunjang dengan bantuan peningkatan kemampuan kewirausahaan, ketrampilan dan pendidikan, penduduk lokal akan mendapatkan nilai tambah dan apresiasi yang lebih besar terhadap lingkungannya sendiri. Upaya melibatkan pekerja wanita lokal dalam jasa ekowisata, sepanjang sesuai dengan aspek budaya, akan dapat meningkatkan produktifitas diri dan keluarganya (Nugroho, 2011).

\section{Metodologi Penelitian}

Penelitian ini dilakukan pada bulan September 2020 di Kawasan Perkebunan Teh Sirah Kencong yang berada dalam wilayah administrasi Kabupaten Blitar Jawa Timur. Penentuan lokasi penelitian terkait dengan tema penelitian yaitu pengembangan pariwisata berkelanjutan. Dalam penelitian ini berusaha untuk mengkaji bagaimana dampak Covid-19 terhadap pengelolaan Agrowisata Sirah Kencong dan menemukan serta mendeskripsikan potensi-potensi yang ada di daerah tujuan wisata berupa potensi 
fisik maupun non fisik sebagai obyek wisata berkelanjutan.

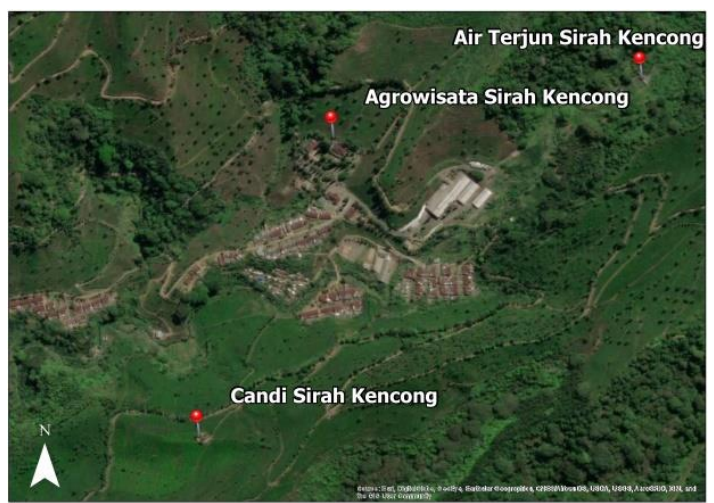

Gambar 1.Peta Lokasi Penelitian di Kawasan Perkebunan Teh Sirah Kencong

Sumber: diolah oleh peneliti

Penelitian ini bersifat deskriptif kualitatif dengan metode survei dan studi kepustakaan. Bersifat deskriptif yaitu suatu metode penelitian yang berusaha mendeskripsikan atau menggambarkan/melukiskan fenomena atau hubungan antar fenomena yang diteliti dengan sistematis, faktual dan akurat (Nazir, 2003). Teknik pengumpulan data dengan data primer dan data sekunder. Pengumpulan data primer menggunakan metode observasi dan wawancara yang berpedoman pada Sapta Pesona Indonesia. Observasi dilakukan dengan datang langsung ke lapangan untuk mengamati kondisi yang ada di Kawasan Perkebunan Teh Sirah Kencong. Wawancara dilakukan terhadap pengelola wisata dan pengunjung. Pengumpulan data sekunder ini didapat dari studi literatur dan mempelajari dokumen dari Pemerintah Kabupaten Blitar dan Dinas Pariwisata Kabupaten Blitar.

Subjek dalam penelitian ini adalah obyek wisata yang berada di kawasan Perkebunan Teh Sirah Kencong dan daerah di sekitarnya. Pengambilan informan dilakukan dengan pertimbangan pada kebutuhan data yang ingin diperoleh yang mengacu pada permasalahan yang digarap dalam penelitian ini. Informan yang digunakan dalam penelitian ini terdiri dari: (1) Pengelola; dan (2) wisatawan. Jumlah masyarakat yang akan dijadikan informan dalam penelitian adalah dengan menggunakan pendekatan purposive sampling. Purposive sampling adalah teknik penentuan sampel yang dilakukan secara sengaja untuk menunjuk orang-orang yang dianggap mampu memberikan kebutuhan data yang diperlukan (Ernaldi, 2010).

\section{Hasil dan Diskusi}

Pandemi Covid-19 yang merebak di masyarakat sempat memberhentikan aktivitas dunia pariwisata. Pemberhentian aktivitas wisata ini juga terjadi di Agrowisata Sirah Kencong yang sempat tutup pada bulan Maret 2020. Penutupan wisata ini berlangsung sampai ada izin dari Dinas Pariwisata Kabupaten Blitar. Aktivitas wisata di Kabupaten Blitar baru bisa dibuka pada 06 Agustus 2020.

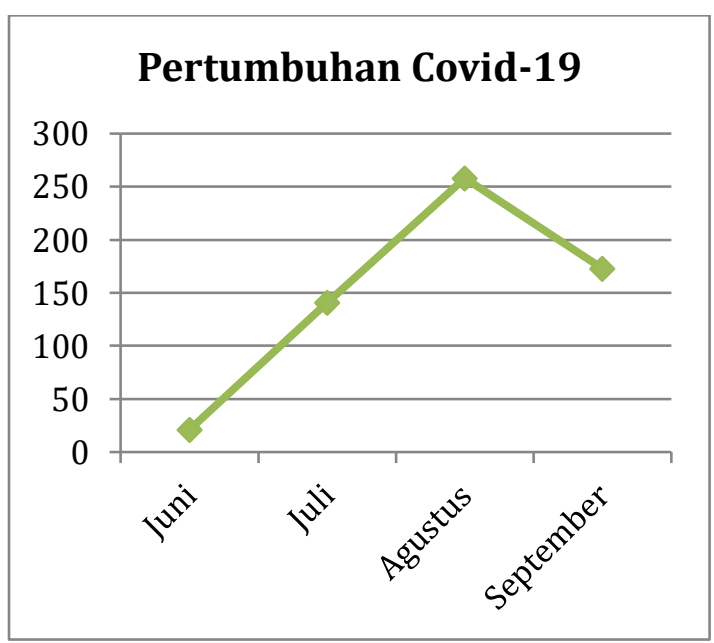

Grafik 1. Grafik Kasus Covid-19 di Kabupaten Blitar Bulan Juni-September 2020

Sumber: diolah oleh peneliti

Berdasarkan grafik tersebut, kasus Covid19 di Kabupaten Blitar pada bulan Juni hingga Agustus terus mengalami peningkatan yang signifikan. Hal ini disebabkan karena swab test yang dilaksanakan oleh Dinas Kesehatan dan Satgas Covid-19 masih massif. Pada bulan Agustus hingga September, kasus Covid-19 mulai mengalami penurunan. Penurunan ini mungkin terjadi karena masyarakat sudah mulai sadar dalam menerapkan protokol kesehatan. Penerapan protokol kesehatan di masyarakat merupakan himbauan dari pemerintah Kabupaten Blitar kepada camat di masing-masing kecamatan, sehingga sosialisasi dan pengawasan lebih tepat sasaran.

Berdasarkan hasil survei Dinas Pariwisata Kebudayaan Pemuda dan Olahraga (Disparbudpora) Kabupaten Blitar pada bulan Juni, bahwa peningkatan kasus Covid-19 ini berdampak pada destinasi wisata di Kabupaten Blitar yang mencapai angka 84.4 persen. Hal tersebut juga berdampak pada kerugian materi yang dialami oleh para pengelola wisata. Sebanyak 59.4 persen 
pengelola mengalami kerugian di bawah $\mathrm{Rp}$ 100 juta, 25 persen kerugian berada di antara Rp 100 juta sampai dengan Rp 500 juta, 12,5 persen kerugian berkisar antara Rp 50 juta sampai dengan Rp 1 milyar, dan sebanyak 3,1 persen kerugian berada di atas $\mathrm{Rp} 1$ milyar (Dinas Pariwisata Kebudayaan Pemuda dan Olahraga, 2020).

Meskipun pandemi ini merugikan para pengelola wisata, tetapi pengelola memiliki upaya dalam menarik perhatian wisatawan yaitu dengan media promosi. Untuk mendongkrak kunjungan wisata pasca pandemi, Pemerintah Kabupaten Blitar melalui Dinas Pariwisata Kebudayaan Pemuda dan Olahraga (Disparbudpora) membuat strategi yang dapat digunakan sebagai penunjang di sektor pariwisata. Strategi tersebut merupakan inovasi dalam teknologi dengan menggunakan aplikasi berbasis website dan android. Aplikasi tersebut diberi nama 'SASMITA' (Sistem Data Aplikasi Promosi Wisata). Tujuan dari pembuatan aplikasi ini adalah untuk melengkapi pelayanan kepada masyarakat di bidang informasi dan promosi pariwisata. Aplikasi ini berfungsi sebagai pelayanan terhadap para pengelola wisata dan wisatawan, sehingga dengan adanya sinergitas antara pemerintah dengan pelaku wisata diharapkan pariwisata di Kabupaten Blitar bisa pulih kembali (Balitar, 2020).

Saat ini Kabupaten Blitar telah membuka kembali dua belas destinasi wisata setelah tutup sementara saat masa darurat pandemi Covid-19. Hal ini dilakukan dalam rangka memfungsikan kembali pariwisata sebagai bagian dari agenda pembangunan daerah. Baru-baru ini Pemerintah Kabupaten Blitar membahas mengenai Industri Pariwisata dan Ekonomi Kreatif via webinar bersama Kepala Disbudpar Jawa Timur Sinarta, Kepala Dinkes dr. Kuspardani, Kepala Disparbudpora Suhendro Winarso, dan Ketua Bapparda Kabupaten Blitar Akhsin Al Fata di Pendopo Ronggo Hadinegoro. Pembahasan kebijakan pada dua sektor tersebut, dibutuhkan untuk mempersiapkan apa yang akan dilakukan di era new normal atau tatanan kehidupan baru. Sementara tema yang dibahas yakni Kabupaten Blitar Menuju Wisata New Normal. Terkait pariwisata di era new normal, bupati memaparkan bahwa Kabupaten Blitar tengah melakukan penataan terkait skema dan standar operasional prosedur (SOP) pengelolaan wisata di tengah pandemi (Pemerintah Kabupaten Blitar, 2020b)

Untuk berhasil dalam suatu kegiatan maupun program, keterlibatan para pemuda millenial sangat diperlukan apalagi mengenai sektor kepariwisataan. Suhendro Winarso sebagai Kepala Dinas Pariwisata, Kebudayaan, Pemuda dan Olahraga (Disparbudpora) Kabupaten Blitar mengajak untuk melibatkan para pemuda sebagai inovator, pendobrak maupun pelaku aktif di kegiatan-kegiatan (Pemerintah Kabupaten Blitar, 2020a).

Agrowisata Sirah Kencong PTPN XII merupakan kawasan andalan untuk pembangunan pariwisata. Kawasan ini sudah ramai sejak dahulu tetapi baru dikelola dan dibuka untuk wisatawan pertama kali pada tahun 2017. Kawasan Agrowisata Sirah Kencong ini memiliki luas kurang lebih 50 ha. Sejak dibukanya kawasan ini sebagai obyek wisata, kawasan ini semakin ramai dikunjungi.

Masa pandemi seperti ini, manajemen pariwisata di Agrowisata Sirah Kencong dilakukan dengan mengikuti protokol kesehatan seperti pengunjung harus memakai masker, mencuci tangan saat memasuki area wisata, dan menjaga jarak antar pengunjung. Sebelum memasuki area wisata, suhu tubuh para pengunjung dicek terlebih dahulu menggunakan termo gun. Himbauanhimbauan seperti spanduk dan banner terpasang di area lokasi wisata yang menghimbau para pengunjung untuk menggunakan masker.

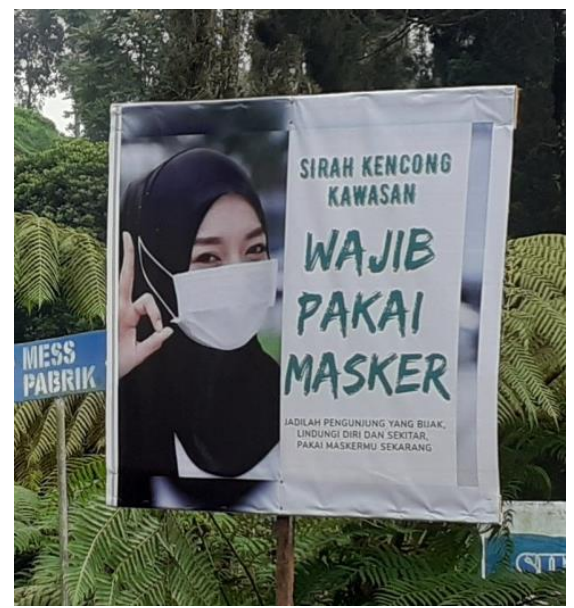

Gambar 2. Banner pemberitahuan wajib pakai masker Sumber: dokumen peneliti 
Pengunjung yang ingin berwisata ke Agrowisata Sirah Kencong cukup membayar tiket masuk Rp 5.000 per orang. Tiket restribusi parkir juga diberlakukan dengan retribusi parkir motor sebesar $\mathrm{Rp} 2.000$, sedangkan mobil Rp 3.000. Harga tiket masuk sangat terjangkau dan cocok untuk berwisata bersama keluarga. Selain tempat parkir untuk wisatawan, pengelola wisata juga menyediakan tempat parkir bagi pengunjung yang ingin mendaki. Sayangnya tempat parkir yang disediakan kurang luas, sehingga pengunjung yang ingin mendaki harus pintar mencari tempat parkir. Hal ini dapat menjadi tinjauan kembali pihak pengelola untuk dapat merencanakan pembangunan tempat parkir khusus pendaki.

Wukir negoro merupakan jalur pendakian ke Gunung Buthak. Jalur ini merupakan perbatasan dari kebun teh menuju hutan dan terdapat area datar yang luas seperti lapangan. Untuk menuju wukir negoro diperlukan waktu kurang lebih 75 menit dari pos masuk Sirah Kencong dengan berjalan kaki. Banyak wisatawan yang berkemah di wukir negoro atau istilah lainnya adalah camping ceria. Hal ini karena pendaki tidak perlu sampai ke Gunung Buthak namun bisa mendapatkan view Gunung Kelud yang indah, terlebih wisatawan dapat melihat matahari terbenam dan matahari terbit. Pihak pengelola menjelaskan bahwa di wukir negoro tersebut pemandangannya sangat bagus, sehingga dapat dijadikan lokasi bumi perkemahan maupun acara seperti PA, dan rencananya nanti akan dikelola dan dikembangkan.

Agrowisata Sirah Kencong pada awalnya memiliki pemandu wisata. Namun karena masa pandemi yang masih berlangsung, dari pihak pengelola belum memberanikan diri untuk menyediakan pemandu wisata, sehingga kunjungan wisata hanya difokuskan pada wisata alamnya saja. Obyek-obyek wisata baru juga diperkenalkan seperti panggung papan berbentuk gitar. Menariknya, lokasi panggung gitar tersebut bersebelahan dengan Candi Sirah Kencong peninggalan Kerajaan Singosari. Pengelola juga memiliki tujuan untuk lebih mengenalkan peninggalan sejarah tersebut. Hal ini dikarenakan wisatawan jarang mengetahui lokasi peninggalan sejarah tersebut dan hanya berfokus pada pemandangan kebun teh saja.

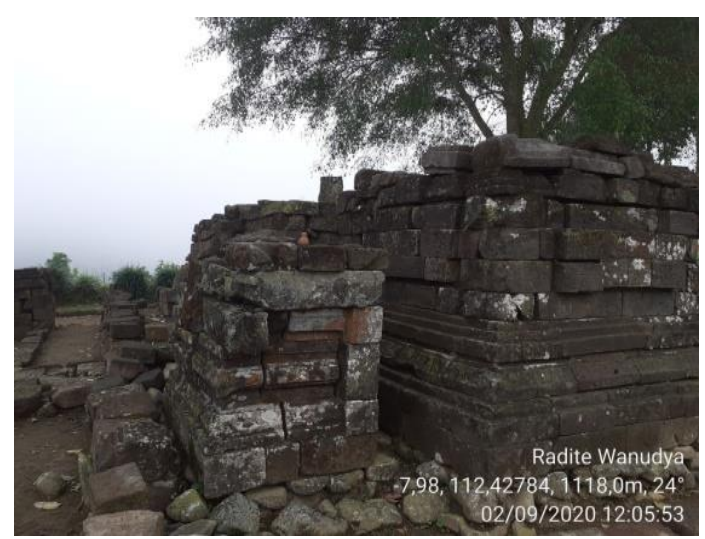

Gambar 3. Candi Sirah Kencong peninggalan Kerajaan Singosari

Sumber: dokumen peneliti

Pengunjung dapat mencapai lokasi obyek dengan berjalan kaki atau dengan menaiki ojek warga sekitar. Jasa ojek dipatok dengan tarif pulang pergi menuju panggung gitar dan Candi Sirah Kencong sebesar Rp 25.000. Salah satu tukang ojek yang juga adalah kepala dusun desa tersebut tak segan menceritakan sejarah Candi Sirah Kencong kepada para pengunjung yang memakai jasanya.

Pengelola juga menyediakan fasilitas berupa satu unit villa dengan harga $\mathrm{Rp}$ 1.000.000 per malam. Fasilitas penunjang lainnya seperti toilet umum, mushola, parkiran motor dan mobil, tempat cuci tangan telah disediakan oleh pihak pengelola. Akses untuk menuju Perkebunan Teh Sirah Kencong sangat mudah, jalannya sudah beraspal dan juga dapat dialui motor atau mobil. Akses ini hanya bisa menggunakan kendaraan pribadi, dan tidak ada kendaraan umum yang melintas. Apabila dari luar kota ingin menggunakan kendaraan umum, maka dari Pasar Wlingi dapat menaiki ojek menuju lokasi perkebunan teh ini. 


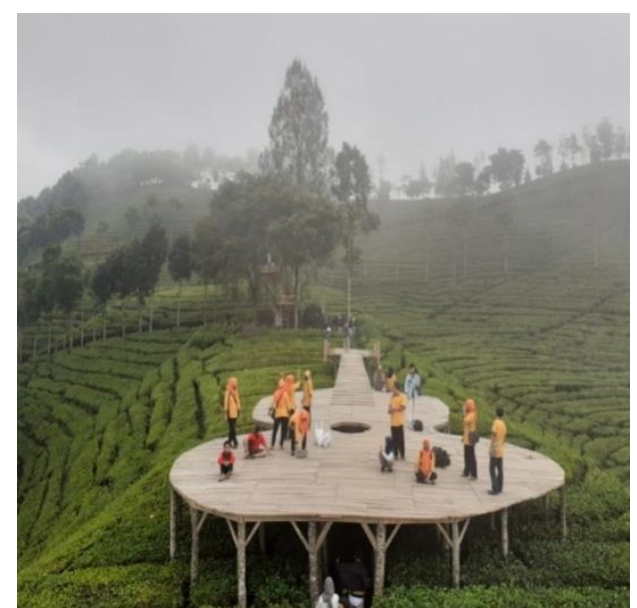

Gambar 4. Spot selfie di Agrowisata Sirah Kencong Sumber: dokumen peneliti

Daya tarik unggulan di Agrowisata Teh Sirah Kencong adalah spot selfie di tengahtengah kebun teh, di mana di spot selfie tersebut pengunjung dapat berfoto dengan latar belakang hamparan kebun teh. Oleh karena itu, daya tarik unggulan di Agrowisata Teh Sirah Kencong terus dikembangkan oleh pihak pengelola. Dalam tiga bulan sekali, pihak pengelola sudah menambah spot selfie, sehingga dalam 2 minggu terakhir ini jumlah pengunjung pada hari minggu dapat mencapai 1500 pengunjung. Pihak pengelola menyampaikan bahwa fokus utama dari wisata alam yang disuguhkan adalah agar pengunjung dapat merasa nyaman.

Di setiap perkebunan teh pasti tidak luput dari adanya pabrik pembuatan teh. Pabrik tersebut bernama KEN TEA. Di pabrik ini, pengunjung dapat melihat-lihat area pabrik dari luar. Produk olahan perusahaan KEN TEA adalah ROLAS yang berupa teh bubuk, teh celup, dan kopi. Pengunjung dapat membeli produk olahan teh di dekat pabrik dan juga di loket atau pintu masuk Agrowisata Sirah Kencong. Produk ini memiliki harga yang cukup terjangkau untuk teh mulai dari Rp 9.000 - Rp 15.000. Produk KEN TEA (ROLAS) juga dipasarkan di area lokal Blitar dan di Malang. Namun sejak pandemi Covid-19 ini sangat berpengaruh pada penjualan yang menurun.

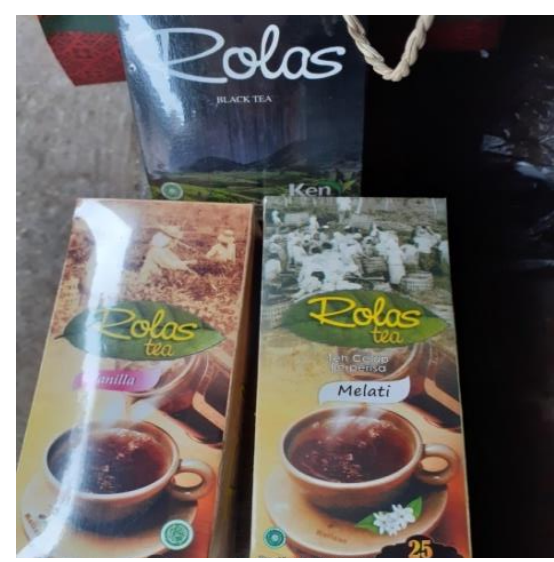

Gambar 5. Produk KEN TEA (ROLAS)

Sumber: dokumen peneliti

Pihak perusahaan sedikit kesulitan dalam penjualan produk teh di masa pandemi ini, sehingga pada weekend warga sekitar mengadakan pasar kaget yang bernama Pasar Kangen Sirah Kencong. Hal ini bertujuan untuk mencari tambahan dengan kondisi pandemi. Di Pasar Kangen ini, terdapat bazar yang menjual makanan khas, tanaman hias dan sayuran, kesenian dan dolanan tradisional. Di dekat pemukiman warga juga terdapat toko bunga hias. Pengunjung juga bisa membeli oleh-oleh produk buatan ibuibu IKBI (Ikatan Keluarga Besar Ibu-Ibu) PTPN XII Sirah Kencong.

Pengembangan yang dilakukan pengelola Agrowisata Sirah Kencong terus dilaksanakan, mengingat semakin meningkatnya wisatawan yang datang. Peningkatan ini akan menambah kebutuhan akan akomodasi, yang mana villa di Sirah Kencong masih ada satu dan ada beberapa cottage. Kondisi ini mendorong pengelola untuk menambah akomodasi. Akomodasi tersebut ditujukan untuk wisatawan yang berasal dari luar Kabupaten Blitar dan dari latar belakang ekonomi menengah ke atas yang ingin melihat nuansa alam dan pemandangan yang indah di Perkebunan Teh Sirah Kencong. Hal ini dikarenakan tarif akomodasi yang dikeluarkan memiliki harga yang cukup mahal. Seiring dengan pengembangan agrowisata, terdapat beberapa hambatan-hambatan yang menghambat jalannya kegiatan wisata dan juga pengembangannya. Hambatan tersebut adalah biaya dan hambatan bencana tanah longsor yang sering terjadi di musim hujan karena lokasi yang berada di lereng-lereng bukit (Elyani, 2019). 
Kawasan Ekowisata perlu dikembangkan dengan konsep berwawasan lingkungan agar terwujud pariwisata berkelanjutan, tidak menimbulkan kerusakan pada lingkungan dan memberikan jaminan kehidupan yang layak bagi masyarakat di sekitarnya, baik sekarang maupun di masa yang akan datang (Insani et al., 2019). Menurut evaluasi wisatawan, berpendapat bahwa perlunya perbaikan maupun strategi untuk keberlanjutan Agrowisata Sirah Kencong yakni dengan menambah jumlah tempat sampah. Ketersediaan tempat sampah di lokasi wisata sebenarnya sudah cukup tersedia namun perlu ditambah kuantitasnya supaya pada saat weekend tiba, dapat meminimalkan angka wisatawan yang membuang sampah sebarangan. Kemudian perlunya memperluas area parkir sehingga tidak memakan bahu jalan terutama untuk kendaraan roda empat. Terkait jaringan komunikasi di sekitar Kawasan Perkebunan Teh Sirah Kencong bisa diperbaharui sehingga memudahkan komunikasi dengan dunia maya ketika wisatawan berada di sana. Selain itu juga, perlunya perbaikan sistem pedagang supaya lebih terkelola dengan rapi. Terkait aksesbilitas jalan untuk menuju air terjun perlu diperbaiki agar memudahkan wistawan dalam mencapai tujuan, karena kondisi jalan menuju air terjun berupa jalan setapak yang notabene memiliki jenis tanah liat yang jika terjadi hujan maka jalanan akan licin.

Demi mencapai keberlanjutan ekowisata, maka diperlukan tahap edukasi yang mana sesuai dengan evaluasi tanggapan wistawan bahwa perlunya untuk suatu produk pariwisata dalam menyuguhkan pembelajaran berupa satu ruangan (mini museum). Tujuannya adalah sebagai wadah untuk edukasi bagaimana tata cara membuat teh. Sebenarnya sudah terdapat wisata museum teh di Agrowisata Sirah Kencong yang memberikan pengetahuan terhadap wisatawan mengenai jenis-jenis tanaman teh. Oleh karena itu, hal tersebut perlu dikaji ulang oleh pengelola wisata mengenai promosi produk wisata, sehingga nantinya pihak pengelola wisata dapat mengagendakan pembuatan brosur tentang obyek-obyek wisata yang ada di Agrowisata Sirah Kencong sehingga lebih dikenal oleh masyarakat.
Dengan demikian, peran pemerintah daerah dalam pengembangan pariwisata untuk menghasilkan nilai tambah dalam konservasi lahan dapat membantu dengan pengembangan kapasitas lokal, memperbaiki insfrastruktur, menonjolkan integrasi promosi, maupun dengan pengembangan produk (Nugroho \& Dahuri, 2012). Perlu diingat bahwa salah satu dampak negatif dari suatu wisata yakni akibat dari kehadiran wisatawan yang berlebihan ke suatu tempat yang tidak dapat dihindari. Untuk itu, suatu negara atau pun masyarakat setempat perlu membuat batasan pemberian informasi yang baik kepada calon wisatawan yang akan datang. Salah satu solusi yang dapat diterapkan adalah dengan mengatur ambang batas jumlah rombongan karena jumlah pengunjung pariwisata akan terus mengalami peningkatan di setiap waktu (Yoeti, 2000). Hal ini sesuai dengan tanggapan wisatawan yang berkunjung ke Agrowisata Sirah Kencong, bahwa pengunjung pada saat weekend selalu banyak dan seharusnya pengelola perlu membatasi jumlah wisatawan. Jika memungkinkan, perlu penyediaan web/situs yang bisa diakses oleh masyarakat dengan sistem booking terlebih dahulu sebelum ke tujuan wisata. Hal ini bertujuan agar wisata tetap terjaga keberlanjutannya. Kondisi tersebut efektif menjadi solusi yang dapat diterapkan oleh pengelola wisata, dan dapat berkaca dari Taman Nasional di Jawa Timur yang menerapkan sistem booking. Tiket masuk yang murah menjadikan wisatawan membludak pada saat weekend di mana masyarakat ingin melepas penat di alam bebas pada saat pandemi seperti sekarang ini.

\section{Kesimpulan}

Kabupaten Blitar bagian utara memiliki kawasan perkebunan teh yang luas yaitu Perkebuan Teh Sirah Kencong yang termasuk bagian dari PT Perkebunan Nusantara XII Bantaran dengan lokasi administratif berada di Desa Ngadirenggo Kecamatan Wlingi. Manajemen pariwisata Agrowisata Sirah Kencong telah dikelola dengan baik. Banyak perkembangan namun ada beberapa obyek yang belum dikembangkan oleh pihak pengelola seperti lokasi bumi perkemahan Wukir Negoro dan lokasi parkir khusus pendaki. Agrowisata 
Sirah Kencong memiliki jumlah pengunjung yang terus meninggkat tiap minggunya di masa pandemi terlebih pada saat weekend, sehingga pengelola perlu megkaji ulang terkait jumlah pengunjung dengan membatasi jumlah wisatawan. Potensi alam lainya dapat dimanfaatkan dan dikembangkan tentunya dengan melihat aspek yang terkait dengan mengedepankan pariwisata secara berkelanjutan.

\section{References}

Balitar. (2020). Dongkrak Kunjungan Wisata Pasca Pandemi, Disparbudpora Luncurkan Website Sasmita. http://balitar.id/dongkrak-kunjunganwisata-pasca-pandemi-disparbudporaluncurkan-website-sasmita/

Dianawanti, V., (2020). Wisata Ramah Lingkungan Bakal Jadi Tren Traveling 2020 Setelah Pandemi Berakhir. https://www.fimela.com/lifestylerelationship/read/4271783/wisataramah-lingkungan-bakal-jadi-trentraveling-2020-setelah-pandemiberakhir (Diakses pada 9 Oktober 2020).

Dinas Kesehatan Kabupaten Blitar. (2020). Info Covid-19 Kabupaten Blitar. https://tanggapcorona.blitarkab.go.id/w p-content/uploads/2020/10/InfografisCovid19-7-oktober-01.png (Diakses pada 8 Oktober 2020).

Dinas Pariwisata Kebudayaan Pemuda dan Olahraga. (2020). Dampak Corona terhadap Pengelola Destinasi Wisata. http://disparbudpora.blitarkab.go.id/202 0/dampak-corona/gallery/ (Diakses pada 9 Oktober 2020).

Djafar, S. (2015). Evaluasi Kebijakan Pariwisata. ombak.

Elyani. (2019). Analisa Dampak Ekonomi Pengembangan Agrowisata Pada Kehidupan Pekerja Perkebunan Ptpn Xii Sirah Kencong Blitar. Jember: Fakultas Ilmu Sosial dan Ilmu Politik. Universitas Jember.

Ernaldi, E. M. (2010). Analisis Strategi Pengembangan

Agrowisata
Perkebunan Teh Gunung Mas Ptpn Viii Bogor, Jawa Barat. Jawa Barat: Bogor, Departemen Agribisnis Fakultas Ekonomi dan Manajemen Institut Pertanian Bogor

Farisa, F. C. (2020). Angka Kematian akibat Covid-19 di Indonesia Lebih Tinggi dari Rata-rata Dunia. https://nasional.kompas.com/read/2020/ 08/31/17050911/angka-kematianakibat-covid-19-di-indonesia-lebihtinggi-dari-rata-rata (Diakses pada 9 Oktober 2020).

Hadi, S. (2020). Banyak Tempat Wisata Ditutup Imbas Covid-19, PAD Pariwisata di Kota Blitar Diturunkan $\begin{array}{llll}\text { Jadi } & R p & 1,4 & M\end{array}$ https://jatim.tribunnews.com/2020/05/3 1/banyak-tempat-wisata-ditutup-imbascovid-19-pad-pariwisata-di-kota-blitarditurunkan-jadi-rp-14-m(Diakses pada 8 Oktober 2020).

Insani, N., Kusuma Sanjiwani, P., \& Ramadhoan, F. (2019). Studi Kesesuaian dan Strategi Pengelolaan Ekowisata Pantai Ungapan, Kabupaten Malang Untuk Pengembagan Pariwisata Berkelanjutan.Jurnal Teori dan Praksis Pembelajaran IPS Volume 4, No.1, 2019, ISSN 2503-5307.

Islamiarani. (2008). Analisis Kinerja Agrowisata Dengan Pendekatan Balanced Scorecard di Kampong Wisata Cinangneng Kecamatan Ciampea Kabupaten Bogor [skripsi]. Fakultas Pertanian, Institut Pertanian Bogor.

Kementrian Kesehatan Repulik Indonesia. (2020). Info Infeksi Emerging Kementrian Kesehatan Republik Indonesia.

https://infeksiemerging.kemkes.go.id/ (Diakses pada 9 Oktober 2020).

Nazir, M. (2003). Metode Penelitian. Ghalia Indonesia.

Nugroho, I. (2011). Ekowisata dan Pembangunan Berkelanjutan. pustaka pelajar.

Nugroho, I., \& Dahuri. (2012). Pembangunan Wilayah Perspektif Ekonomi, Sosial dan Lingkungan. 


\section{LP3ES.}

Pemerintah Kabupaten Blitar. (2020a). Bahas Kepariwisataan, Kadisparbudpora Kabupaten Blitar Butuh Keterlibatan Pemuda Millenial Membangun Program.

https://www.blitarkab.go.id/2020/09/03/ bahas-kepariwisataan-kadisparbudporakabupaten-blitar-butuh-keterlibatanpemuda-millenial-membangunprogram/(Diakses pada 9 Oktober 2020).

Pemerintah Kabupaten Blitar. (2020b). Di Bulan Bung Karno, Bupati Blitar Bahas Industri Pariwisata dan Ekonomi Kreatif Via Webinar. https://www.blitarkab.go.id/2020/06/06/ di-bulan-bung-karno-bupati-blitarbahas-industri-pariwisata-dan-ekonomikreatif-via-webinar/(Diakses pada 9 Oktober 2020).

Pemerintah Kabupaten Blitar. (2020c). Gambaran Umum. https://www.blitarkab.go.id/2012/06/06/ gambaran-umum2/\#: :text=Kabupaten\%2520Blitar\%25 20memiliki\%2520luas\%2520wilayah,y ang\%2520sekaligus\%2520membedaka n\%2520potensi\%252(Diakses pada 11 Oktober 2020)

Rahma, P. D., \& Primasworo, R. A. (2018). Strategi Pengembangan Desa Wisata Di Kecamatan Karangploso Kabupaten Malang. Neo-Bis, 11(2), 142. https://doi.org/10.21107/nbs.v11i2.3381

Sawindri, A. A. (2016). Pengembangan Kampung Wisata Ekologi (KWE) "Puspa Jagad" Sebagai Destinasi Ekowisata di Desa Semen Kecamatan Gandusari Kabupaten Blitar.Yogyakarta : Universitas Negeri Yogyakarta.

Wuragil, Z. (2020). COVID-19 di Asia Tenggara: Malaysia Terbanyak, Indonesia Terfatal. TEMPO.CO. https://tekno.tempo.co/read/1325424/co vid-19-di-asia-tenggara-malaysiaterbanyak-indonesia-terfatal(Diakses pada 10 Oktober 2020).

Yoeti, O. (2000). Ekowisata Pariwisata Berwawasan Lingkungan. PT pertja. 


\section{Surat Pernyataan Orisinalitas}

Saya yang bertanda tangan di bawah ini :

Nama : Radite Wanudya Apsari

NIM : 180722639583

NIK : 3505175211990002

Asal Perguruan Tinggi : Universitas Negeri Malang

Nomor Telepon : 085846240516

Menyatakan dengan sesungguhnya bahwa Paper dengan judul: Dampak Covid-19

Terhadap Pengelolaan Agrowisata Perkebunan Teh Sirah Kencong Kabupaten Blitar sebagai Obyek Wisata Berkelanjutan

Yang saya ajukan dalam Call For Paper yang diselenggarakan oleh Politeknik Negeri Samarinda adalah Paper yang kami yang belum pernah publikasikan sebelumnya di media manapun, dan belum pernah diikutsertakan dalam perlombaan/kompetisi sejenis, dan/atau tidak pernah digunakan untuk media komunikasi apapun, serta bukan hasil dari plagiat.

Apabila pernyataan saya tersebut di atas di kemudian hari tidak benar, saya bersedia dituntut sesuai dengan peraturan dan perundang-undangan yang berlaku.

Demikian Surat Pernyataan ini saya buat dalam keadaan sadar dan tanpa paksaan dari pihak manapun untuk dapat dipergunakan sebagaimana mestinya.

Blitar, 11 Oktober 2020

Yang membuat pernyataan,

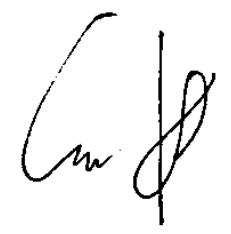

Radite Wanudya Apsari 